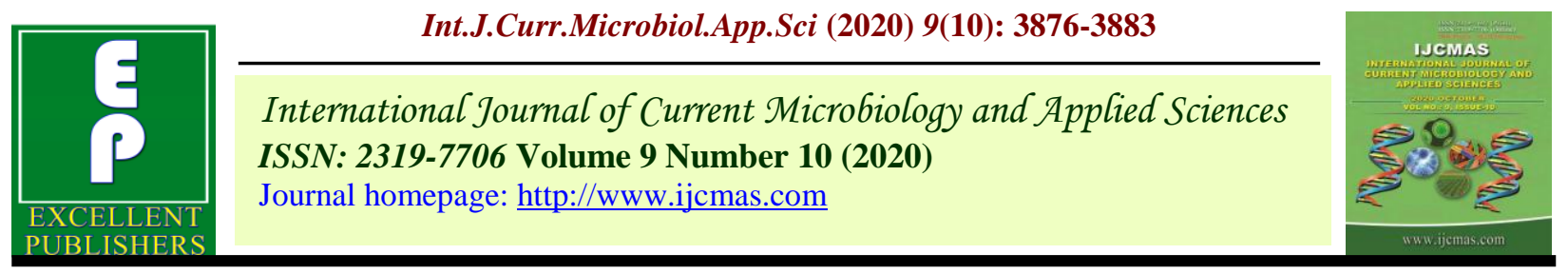

\title{
Serotyping and Prevalence of Escherichia coli Infection in Poultry of South Gujarat based on Culture Isolation and Identification
}

\author{
Pratik P. Panchal ${ }^{1}$, Jignesh M. Patel ${ }^{1 *}$, Priti D. Vihol ${ }^{1}$, J. K. Raval ${ }^{1}$, \\ D. R. Patel $^{2}$, Nikhil Danger ${ }^{3}$, I. H. Kalyani ${ }^{2}$ and N. M. Patel ${ }^{4}$ \\ ${ }^{1}$ Department of Veterinary Pathology, ${ }^{2}$ Department of Veterinary Microbiology, ${ }^{3}$ Department \\ of Animal Genetics and Breeding, ${ }^{4}$ Department of Veterinary Public Health, Vanbandhu \\ College of Veterinary Sciences and Animal Husbandry, Navsari Agricultural University, \\ Navsari, Gujarat, India \\ *Corresponding author
}

\section{A B S T R A C T}

Keywords

E. coli, Poultry, Isolation and Identification, Serotyping, Prevalence

Article Info

Accepted:

25 September 2020 Available Online: 10 October 2020
In the present study, total 290 swab samples collected from organized poultry farms located in Navsari and Valsad districts and screened for prevalence study and different serotype of $E$. coli infection using culture isolation and identification. Isolation and identification resulted out of 290 swab samples 207 isolates produced lactose fermenting pink colored colonies on MacConkey agar, produced colonies with greenish metallic sheen on EMB agar and grams staining revealed typical gram-negative rods morphologically similar to E. coli. With culture isolation and identification overall prevalence was 71.38 per cent. District wise prevalence in Navsari and Valsad districts was 74.00 per cent and 65.56 per cent, respectively. Broiler birds showed higher prevalence $(74.00,148 / 200)$ rate in comparison to Layer birds $(65.56,59 / 90)$. Significantly prevalence was comparatively higher in January $(90.21 \%)$ followed by September $(78.78 \%)$, December $(69.38 \%)$, August $(51.85 \%)$ and November $(40 \%)$ months. The age wise high prevalence was 82.14 per cent and 55.00 per cent in 0-30 days and 31-35 days of age group, respectively in broiler birds and 68.51 per cent and 61.11 per cent in 40-45 days and 46-50 days of age group, respectively in layer birds. As per resulted National Salmonella and E. coli Center, Kasauli, 15 different serotypes out of 35 isolates, two of $\mathrm{O} 8$, two of $\mathrm{O35}$, four of O83, three of O88, two of O119 and two of O149. High prevalence of serotype O83 (11.42\%) followed by O88 (8.57), O8 (5.71), O35 (5.71), O119 (5.71) and O149 (5.71\%).

\section{Introduction}

Escherichia coli (E.coli) is a part of normal intestinal microflora of fowls and mammals. Under some conditions bacteria of the normal flora may become harmful to the host. Moreover such as a high stocking density, poor hygiene condition, poor litter, high ammonia level and other stressful situation may reduce the resistance of the birds and increase the susceptibility to infections. E. coli belongs to the Enterobacteriacea family and in India first reported of collibacillosis in brooder chicks by Gurumoorthy and 
Panduranga Rao (1962). Cellulitis could develop at any age of birds and the lesions associated with other manifestation of collibacillosis like air sacculitis, pericarditis and perihepatitis in chicken mostly four to six weeks of age reported by Jonhson et al., (2001).

Serotype of E.coli are present approximately $180 \mathrm{O}, 60 \mathrm{H}$, and $80 \mathrm{~K}$ antigens. In most serological typing scheme only the $\mathrm{O}$ and $\mathrm{H}$ antigens are determined i.e. O157:H7. The O antigen determines serogroups and heat stable somatic antigen while the $\mathrm{H}$ antigen determines serotype and heat labile flagellar antigen.

In India poultry industry is one of the fastest growing agricultural sectors in the country. Commercial broilers are grown throughout the world and broiler chicken becoming the most affordable, delicious and nutritious protein (Kumari, 2016). The consumption of meat is increasing in India and agriculture is considered as the backbone of a majority of people. The high demand of chicken meat consumption is due to the versatility of the meat, relatively low cost in comparison to the other meat, and the acceptance of the chicken meat to all religions (Kim, 2014). Hence present experiment has been carried out to known status of E.coli in two districts of South Gujarat.

\section{Materials and Methods}

A total 290 swab samples collected from organized poultry farms located in Navsari and Valsad districts screened for prevalence study and different serotype of E.coli infection using culture isolation and identification.

Media and chemicals required for isolation and biochemical characterization of E.coli were prepared as per Cruickshank et al.,
(1973) and Agrawal et al., (2003). Primary isolation of E.coli was done using Mac Conkey agar medium. Lactose fermented pinkish colour colony selected and subcultured on Eosin Methylene Blue agar medium to detect the production of metallic sheen. All the isolates were stained by gram's staining and observed under oil immersion objective for presence of gram negative rods. Biochemical tests like Indole, Methyl-red, Voges-proskauer and Citrate utilization were employed for identification of E.coli (Cruickshank et al., 1973; Agrawal et al., 2003).

Out of 90 E.coli isolates, 35 isolates were selected for serotyping and sent to National Salmonella and Escherichia coli center (NSEC), Central Research Institute (CRI), Kasauli on nutrient agar stab for serotyping.

\section{Results and Discussion}

The district-wise, month-wise, bird type-wise and age-wise prevalence details are given in table-1. Out of 290 swab samples tested, 207 were found positive for E.coli infection yielding an overall prevalence of 71.38 per cent in the birds of the Navsari and Valsad districts. District wise prevalence in Navsari and Valsad districts was 74.00 per cent and 65.56 per cent, respectively.

In the present study, broiler birds showed higher prevalence $(74.00,148 / 200)$ rate in comparison to Layer birds $(65.56,59 / 90)$. In present study higher prevalence of collibacillosis was found in broiler birds than layer which supported by earlier reports of Omer et al., (2010), Srinivasan et al., (2014), Matin et al., (2017) and Rahman et al., (2017). However, Rahman et al., (2004) reported high prevalence of E.coli infection in layer birds. Higher prevalence in broiler than layer in present study might be due to water management and hygiene of deep litter 
housing system which makes broiler more prone to infection. Good housing, hygiene and avoiding overcrowding are very important in reducing infection rates of E.coli (Saidi et al., 2012).

Further, the prevalence of E.coli was significantly higher in January (90.21\%) followed by September (78.78\%), December (69.38\%), August $(51.85 \%)$ and November (40\%) month (Table 4.1). Similarly, Sultana et al., (2012), Mukhtar et al., (2012) and El Sayed et al., (2015) also reported higher prevalence of collibacillosis in winter months. This variation may be attributed to variation in the environmental and hygienic condition in poultry farms. Overcrowding, poor ventilation and high amount of ammonia in air may the attributing factors to increased incidence of E.coli in water, feed, litter and air in winter than summer (Mohamed et al., 2014).

Table.1 District, months, bird type wise and age wise prevalence of E.coli infection in birds

\begin{tabular}{|c|c|c|c|c|}
\hline \multicolumn{2}{|c|}{ Particular } & $\begin{array}{c}\text { No. of sample } \\
\text { ( } n=40 \text { broiler } \\
\text { and } n=18 \text { layer) }\end{array}$ & $\begin{array}{l}\text { No. ofPositive } \\
\text { sample }\end{array}$ & $\begin{array}{l}\text { Percentage of } \\
\text { positive } \\
\text { sample }\end{array}$ \\
\hline \multicolumn{5}{|c|}{ 1. District } \\
\hline Navsari & & 200 & 148 & 74.00 \\
\hline Valsad & & 90 & 59 & 65.56 \\
\hline \multirow{2}{*}{\multicolumn{2}{|c|}{$\begin{array}{c}\text { Total } \\
X^{2}\end{array}$}} & 290 & 207 & 71.38 \\
\hline & & \multicolumn{3}{|c|}{$2.17 \quad(p=0.14)$} \\
\hline \multicolumn{5}{|c|}{ 2. Months } \\
\hline \multicolumn{2}{|l|}{ August } & 27 & 14 & 51.85 \\
\hline \multicolumn{2}{|c|}{ September } & 33 & 26 & 78.78 \\
\hline \multicolumn{2}{|c|}{ November } & 40 & 16 & 40.00 \\
\hline \multicolumn{2}{|c|}{ December } & 98 & 68 & 69.38 \\
\hline \multicolumn{2}{|l|}{ January } & 92 & 83 & 90.21 \\
\hline \multicolumn{2}{|c|}{ Total } & 290 & 207 & 71.38 \\
\hline \multicolumn{2}{|r|}{$X^{2}$} & \multicolumn{3}{|c|}{$41.38 * *(\mathrm{p}=0.00)$} \\
\hline \multicolumn{5}{|c|}{ 3. Bird type } \\
\hline \multicolumn{2}{|l|}{ Broiler } & 200 & 148 & 74.00 \\
\hline \multicolumn{2}{|l|}{ Layer } & 90 & 59 & 65.56 \\
\hline \multirow{2}{*}{\multicolumn{2}{|c|}{$\begin{array}{c}\text { Total } \\
X^{2}\end{array}$}} & 290 & 207 & 71.38 \\
\hline & & \multicolumn{3}{|c|}{$2.17 \quad(\mathrm{p}=0.14)$} \\
\hline \multicolumn{5}{|l|}{ 4. Age } \\
\hline \multirow[t]{2}{*}{ Broiler } & 0-30 days & 140 & 115 & 82.14 \\
\hline & 31-35 days & 60 & 33 & 55.00 \\
\hline \multirow[t]{2}{*}{ Layer } & 40-45 days & 54 & 37 & 68.51 \\
\hline & 46-50 days & 36 & 22 & 61.11 \\
\hline \multirow{3}{*}{\multicolumn{2}{|c|}{$\begin{array}{c}\text { Total } \\
X^{2}\end{array}$}} & 290 & 207 & 71.38 \\
\hline & & \multicolumn{3}{|c|}{$17.90 * *(\mathrm{p}=0.00)$} \\
\hline & & \multicolumn{3}{|c|}{ Note: $* *$ Highly Significant at $\mathrm{P}<0.01$} \\
\hline
\end{tabular}


Table.2 Percent Positive samples of E.coli in Layer and Broiler birds with different sample collection site

\begin{tabular}{|c|c|c|c|c|c|c|c|}
\hline $\begin{array}{l}\text { Total } \\
\text { Layer } \\
(n=18)\end{array}$ & $\begin{array}{l}\text { Sample site with } \\
\text { sample number }\end{array}$ & $\begin{array}{c}\text { Layer } \\
\text { (Positive } \\
\text { Samples) }\end{array}$ & $\%$ & $\begin{array}{c}\text { Total } \\
\text { Broiler } \\
(n=40)\end{array}$ & $\begin{array}{l}\text { Sample site with } \\
\text { sample number }\end{array}$ & $\begin{array}{c}\text { Broiler } \\
\text { (Positive } \\
\text { samples) }\end{array}$ & $\%$ \\
\hline \multirow[t]{5}{*}{18} & Liver (18) & 14 & 77.78 & \multirow[t]{5}{*}{40} & Liver (40) & 35 & 87.50 \\
\hline & Heart (18) & 13 & 72.22 & & Heart (40) & 34 & 85.00 \\
\hline & $\begin{array}{l}\text { Abdominal fluid } \\
\text { (18) }\end{array}$ & 13 & 72.22 & & $\begin{array}{l}\text { Abdominal Fluid } \\
\text { (40) }\end{array}$ & 31 & 77.50 \\
\hline & Yolk sac (18) & 3 & 16.67 & & Spleen (40) & 12 & 30.00 \\
\hline & Intestine (18) & 16 & 88.89 & & Intestine (40) & 36 & 90.00 \\
\hline Total & 90 & 59 & 65.56 & Total & 200 & 148 & 74.00 \\
\hline
\end{tabular}

Table.3 Farm wise prevalence of E.coli infected Poultry

\begin{tabular}{|c|l|c|c|c|c|}
\hline $\begin{array}{c}\text { Sr. } \\
\text { No. }\end{array}$ & Location & $\begin{array}{c}\text { Number } \\
\text { of birds }\end{array}$ & $\begin{array}{c}\text { Number } \\
\text { of } \\
\text { samples }\end{array}$ & $\begin{array}{c}\text { Number of } \\
\text { Positive } \\
\text { samples }\end{array}$ & $\begin{array}{c}\text { Percentage of } \\
\text { positive samples }\end{array}$ \\
\hline 1. & Village:Gourgaon, Valsad & 18 & 90 & 59 & 65.55 \\
\hline $\mathbf{2 .}$ & Village: Abrama, Navsari & 12 & 60 & 54 & 60.00 \\
\hline $\mathbf{3 .}$ & Village:Eru gam, Navsari & 11 & 55 & 42 & 76.36 \\
\hline $\mathbf{4 .}$ & Village: Machad, Navsari & 04 & 20 & 12 & 60.00 \\
\hline $\mathbf{5 .}$ & Village: Mandir, Navsari & 07 & 35 & 17 & 48.57 \\
\hline $\mathbf{6 .}$ & Village: Chikhli, Navsari & 06 & 30 & 23 & 76.66 \\
\hline & Total & $\mathbf{5 8}$ & $\mathbf{2 9 0}$ & $\mathbf{2 0 7}$ & $\mathbf{7 1 . 3 8}$ \\
\hline
\end{tabular}
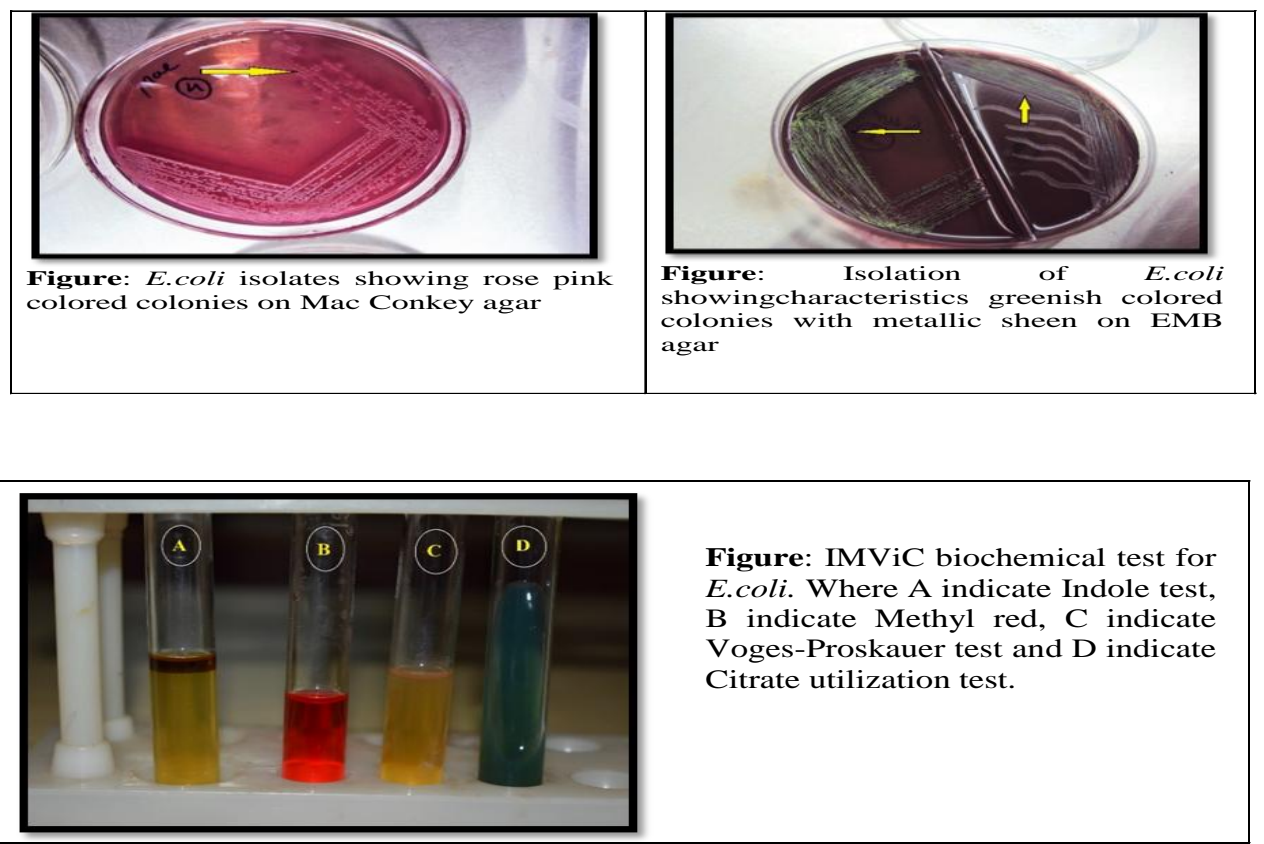

Figure: IMViC biochemical test for E.coli. Where A indicate Indole test, $B$ indicate Methyl red, $C$ indicate Voges-Proskauer test and D indicate Citrate utilization test. 
From the above mentioned results of table- 3 , it is obvious that E.coli isolates were recovered from poultry farms with higher prevalence from intestine sample followed by liver and lung which was also nearly similar result obtained by Yousef et al., (2013).

The prevalence of collibacillosis was differ significantly between different age group of broiler and layer birds. Where in significantly highest 82.14 per cent prevalence of collibacillosis was seen in 0-30 days age group followed by 55.00 per cent prevalence in 31-35 days age group of broiler birds. While in layer, 68.51 per cent prevalence was seen in 40-45 days age group followed by 61.11 per cent prevalence in $46-50$ days age group (Table 4.1).

Biochemical characterization of 207 E.coli isolates was done with Indole test, MR test, VP test, Citrate utilization test and Motility test. Resulted 207 isolates 90 isolates confirmed as E.coli with Indole positive, MR test positive, VP test negative, Citrate negative and also all isolates were found motile which ware similar with the findings of Buxton and Fraser (1977). No atypical or unusual biochemical reaction was shown by any of the 90 isolates tested.

In present study obtained 15 serotypes out of 35 isolates, two of $\mathrm{O} 8$ (5.71), two of $\mathrm{O} 35$ (5.71), four of $\mathrm{O} 83$ (11.42), three of $\mathrm{O} 88$ (8.57), two of O119 (5.71) and two of O149 (5.71). High prevalence of O83 serotype which also further confirmed by PCR using stx 1 and stx 2 gene sequence primer. The fact that $\mathrm{O} 83$ has been associated with human illness (Bettelheim, 2007) raised the possibility that $\mathrm{O} 83$ might be transferred to humans via aerosol route supported by Xia et al., (2010).

The isolated serotype $\mathrm{O} 8$ in present study was already confirmed as virulent serotype by
Kika et al., (2013). Further these serogroups are commonly associated with avian collibacillosis and confirm their role as potential pathogens in the extra intestinal infections of poultry (Dho-Moulin and Fairbrother, 1999; Ewers et al., 2004). Occurrence of different E. coli serotypes which were involved in coli septicaemia and other conditions in chicken were reported from time to time by various researchers viz., Saikia et al., (1995) and Rama Devi (2005). They opined that the outbreaks of the disease might be influenced by the various strains present in the environment and to the extent of intensity of the strains present.

The serotyping of $\mathrm{O}$ groups is in corroboration with the findings of Gross (1994), Saikia et al., (1995) and Rama Devi (2005). It was observed by the researchers that the serotypes of $\mathrm{O}$ were commonly encountered in various respiratory, septicemic and colibacillosis condition in chicken and they identified as many as $154 \mathrm{O}$ serotypes. These $\mathrm{O}$ serotypes were prevalent worldwide with number of serotypes identified as cause of poultry disease (Gross, 1961).

In present study recording of serotype O149 was in accordance with the findings of Frydendahl (2002) where in the researcher reported these one serotype in piglet diarrhoea. It is obvious to say that in multifarming system there is every possibility of cross contamination of serotypes of one species to another. So in the present study samples were collected from the poultry sources which were located nearer to free ranging of pig and cattle population. Therefore it could be possible for cross contamination of $E$. coli serotype from one species to another by possible environmental influences and which could be trespassing of the workers similar result reported by Blanco et al., (1997). 
Serotype 088 isolates by Srinivasan et al., (2014) from commercial caged layer chickens was supported result of present study. Knobl et al., (2011) reported serotype O88 as an Avian Pathogenic Escherichia coli (APEC). O119 serotype was isolated in present study. Similar O119 serogroup was also isolated by H.Kh et al., (2014) and confirmed as Enteropathogenic E.coli (EPEC). Serotype O35 reported by Cloud et al., (1985) from broiler birds affected with collibacillosis except from yolk sac infection sample which was similar to present study.

\section{References}

Agarwal R. K., Bhilegaonkar, K. N., Singh, D. K., Kumar, A. and Rathore, R. S. (2003). Laboratory manual for isolation and identification of food-borne pathogens, (First edition), pp. $30-31$.

Bettelheim, K. A. (2007). The non-O157 Shiga-toxigenic (verocytotoxigenic) Escherichia coli under-rated pathogens. Critical reviews in microbiology, 33(1): 67-87.

Blanco, M., Blanco, J. E., Gonzalez, E. A., Mora, A., Jansen, W., Gomes, T. A. and Blanco, J. (1997). Genes coding for enterotoxins and verotoxins in porcine Escherichia coli strains belonging to different $\mathrm{O}: \mathrm{K}: \mathrm{H}$ serotypes: relationship with toxic phenotypes. Journal of clinical microbiology,35(11): 29582963.

Buxton, A. and Fraser, G. (1977). Animal microbiology. Volume 1: immunology, bacteriology, mycology, diseases of fish and laboratory methods. Blackwell Scientific Publications.

Cruickshank, R., Duguid, J. P., Marmion, B. P. and Swain, R. H. A. (1973). Medical microbiology; a guide to the laboratory diagnosis and control of infectionvolume 1.

Dho-Moulin, M. and Fairbrother, J. M.
(1999). Avian pathogenic Escherichia coli (APEC). Veterinary Research, 30(23): 299-316.

El-sayed, M. E., Shabana, I. I., Esawy, A. M. and Rashed, A. M. (2015). Detection of virulence-associated genes of avian pathogenic Escherichia Coli (APEC) isolated from broilers. Jacobs journal of Genetics, 1(1): 004.

Ewers, C., Janßen, T., Kiebling, S., Philipp, H. C. and Wieler, L. H. (2004). Molecular epidemiology of avian pathogenic Escherichia coli (APEC) isolated from colisepticemia in poultry. Veterinary microbiology, 104(1): 91-101.

Frydendahl, K. (2002). Prevalence of serogroups and virulence genes in Escherichia coli associated with postweaning diarrhoea and edema disease in pigs and a comparison of diagnostic approaches. Veterinary microbiology, 85(2): 169-182.

Gross, W. B. (1961). The development of" air sac disease". Avian Diseases, 5(4): 431439.

Gross, W.B. (1994) Diseases due to Escherichia coli in poultry, in: GYLES, C.L. (Ed) E.coli in domestic animals and man, pp. 237-259 (Wallingford, UK: CAB International).

Gurumurthi, V. and Panduranga Rao, P. (1962). Colibacillosis in brooder chicks. Indian veterinary Journal, 39: 66-69.

H.Kh, Hassan A.M.L. and Bakeet A.M. (2014). Characterization of Escherichia coli strains isolated from infected Pigeons in Assiut province. Assiut Veterinary Medical Journal, 60(142): 29-37.

Johnson, L. C., Bilgili, S. F., Hoerr, F. J., Murtrey, B. M. and Norton, R. A. (2001). The influence of Escherichia coli strains from different sources and the age of broiler chickens on the development 
of cellulitis. Avian Pathology, 30(5): 475-478.

Kika, T. S., Circella, E., Cabeli, P., Cocoli, S. and Camarda, A. (2013). Serotype and biotype prevalence of avian pathogenic Escherichia Coli in Albanian poultry industry. Fourth International Scientific Symposium" Agrosym 2013", Jahorina, Bosnia and Herzegovina, pp.1098-1104.

Kim, I. H., Lee, S. I. and Balachandar, V. (2014). An outline of meat consumption in the indian population - A Pilot review. Korean journal for Food Science of Animal Resources, 34(4): 507-515.

Knobl, T., Saidenberg, A., Moreno, A. M., Gomes, T. A., Vieira, M. A., Leite, D. S. and Ferreira, A. J. (2011). Serogroups and virulence genes of Escherichia coli isolated from psittacine birds. Pesquisa Veterinária Brasileira, 31(10): 916-921.

Kumari, M. (2016). Pathological and Immunological studies on Escherichia coli infection in broiler chickens fed on withania somnifera and aloe vera extracts. Hisar (Doctoral dissertation, LUVAS).

Mahajan, N. K., Jindal, N. and Kulshreshtha, R. C. (1994). Major broiler diseases in some parts of Haryana. Indian Journal of Animal Sciences, 64(11): 1118-1122.

Matin, M. A., Islam, M. A. and Khatun, M. M. (2017). Prevalence of colibacillosis in chickens in greater Mymensingh district of Bangladesh. Veterinary World, 10(1): 29-33.

Mohamed, M. A., Shehata, M. A. and Rafeek, E. (2014). Virulence genes content and antimicrobial resistance in Escherichia coli from broiler chickens. Veterinary medicine international, 24(2): 1-6.

Mukhtar M., Awais, M. M., Anwar, M. I., Hussain, Z., Bhatti, N. and Ali, S. (2012). Seroprevalence of Mycoplasma gallisepticum among commercial layer in Fasilabad, Pakistan. Journal of Basic and Applied Sciences, 8(1): 183-186.
Nehal, A. A. N. (2009). Diversity and prevalence of Escherichia Coli in chickens, environment and related Persons. M.V.Sc. Thesis submitted to Alexandria University.

Omer, M. M., Abusalab, S. M., Gumaa, M. M., Mulla, S. A., Omer, E. A., AlHassan, A. M. and Ahmed, A. M. (2010). Outbreak of colibacillosis among broiler and layer flocks in intensive and semi intensive poultry farms in Kassala State, Eastern Sudan. Asian Journal of Poultry Science, 4(4): 173-181.

Rahman, M. A., Rahman, M. M., Moonmoon, M., Alam, K. J. and Islam, M. Z. (2017). Prevalence of common diseases of broiler and layer at Gazipur district in Bangladesh. Asian Journal of Medical and Biological Research, 3(2): 290-293.

Rahman, M. A., Samad, M. A., Rahman, M. B. and Kabir, S. M. L. (2004). Bacteriopathological studies on salmonellosis, colibacillosis and pasteurellosis in natural and experimental infections in chickens. Bangladesh Journal of Veterinary Medicine, 2(1): 1-8.

Rama Devi, M. (2005). Colibacillosis in Chicken: A Patho - Microbiological study. M.V.Sc. thesis submitted to Acharya N.G. Ranga Agricultural University, Hyderabad.

Saidi, B., Mafirakureva, P. and Mbanga, J. (2012). Antimicrobial resistance of Escherichia coli isolated from chickens with colibacillosis in and around Harare, Zimbabwe. Avian diseases, 57(1): 152154.

Saikia, P. K., Dutta, G. N. and Kalita, C. C. (1995). Serogroups and antimicrobials susceptibility of Escherichia coli from chickens and ducks in Assam. Indian Journal of Comparative Microbiology, 16(3): 158-161.

Srinivasan, P., Balasubramanian, G. A., Murthy, T. R. G. K. and Balachandran, P. (2014). Pathomorphological studies of 
polyserositis in commercial caged layer chicken. Asian Pacific journal of tropical medicine, 7(1): S313-S320.

Sultana, R., Siddique, B., Ali, R. and Chaudhary, S. (2012). A study on the prevalence of respiratory diseases in broiler and layer flocks in and around Lahore district. Punjab University Journal of Zoology, 27(1): 13-17.

Xia, X., Meng, J., McDermott, P. F., Ayers, S., Blickenstaff, K., Tran, T. T. and Zhao, S. (2010). Presence and characterization of Shiga toxinproducing Escherichia coli and other potentially diarrheagenicE. coli strains in retail meats. Applied and environmental microbiology, 76(6): 1709-1717.

Yousef, S. A., Ammar, A. M. and Ahmed, D. A. (2013). Serological and molecular typing of avian pathogenic E.coli originating from outbreaks of colibacillosis in chicken flocks. International Journal of Science and Research, 4(2): 2082-2088.

\section{How to cite this article:}

Pratik P. Panchal, Jignesh M. Patel, Priti D. Vihol, J. K. Raval, D. R. Patel, Nikhil Danger, I. H. Kalyani and Patel, N. M. 2020. Serotyping and Prevalence of Escherichia coli Infection in Poultry of South Gujarat based on Culture Isolation and Identification. Int.J.Curr.Microbiol.App.Sci. 9(10): 3876-3883. doi: https://doi.org/10.20546/ijcmas.2020.910.446 